\title{
HEALTH RISK ASSESSMENT OF HOUSEHOLD EXPOSURE TO INDOOR RADON IN ASSOCIATION WITH THE DWELLING'S AGE
}

\author{
Amin Shahrokhi, Forough Shokraee, Ali Reza, Hasn Rahimi \\ Indoor Air Monitoring and Refining Company Ltd. Tehran, Iran
}

Received June 30, 2015 / 1st Revised August 21, 2015 / Accepted for Publication September 8, 2015

\begin{abstract}
Radon is a naturally occurring radioactive gas and a major indoor contribution of exposure to ionizing radiation in dwellings. ${ }^{222} \mathrm{Rn}$ is a health hazard gas what is responsible for thousand lung cancer deaths every year. In this study, indoor radon concentrations present in thirty representative houses in Mahallat city, Iran, were determined in order to estimate lung cancer risk associated with residential radon exposure. Long-term passive method, using CR-39, was used to measure the radon concentration. The results showed an association between the age of the dwellings and the indoor radon concentration that was found, in that the concentration of radon tended to increase as the age of the dwelling also increased. The indoor radon concentrations were calculated to be within the range of $23 \pm 2$ to $350 \pm 26 \mathrm{~Bq} \cdot \mathrm{m}^{-3}$, with an average of $158 \mathrm{~Bq} \cdot \mathrm{m}^{-3}$. The annual effective dose from inhaled radon and its decay products was calculated between $0.8 \pm 0.1$ and $12.3 \pm 0.9 \mathrm{mSv} \cdot \mathrm{y}^{-1}$, with an average of $5.5 \mathrm{mSv} \cdot \mathrm{y}^{-1}$. By taking into consideration the EPA recommendation and ICRP statement, the average annual risk of lung cancer from inhaled radon was calculated as $0.09 \%, 0.06 \%, 0.01 \%$, and $0.03 \%$ for current smokers (CS), those who had ever smoked (ES), never smokers (NS) and the general population, respectively.
\end{abstract}

Keywords: Indoor radon, Health risk assessment, Lung cancer, CR-39, Dwellings

\section{INTRODUCTION}

Radon is a naturally occurring radioactive gas with the chemical symbols of $\mathrm{Rn}$ and atomic number of 86 . ${ }^{222} \mathrm{Rn}$ is the most stable isotope of radon with a half-life of 3.8 days [1]. ${ }^{222} \mathrm{Rn}$ originates from the decay of ${ }^{226} \mathrm{Ra}$, an element in the decay series of ${ }^{238} \mathrm{U}$, and it is the heaviest gaseous element in natural sequential decay series of uranium, thorium, and actinium. ${ }^{222} \mathrm{Rn}$ and its progeny are major factors for radiation exposure to humans, and are what increases the risk of lung cancer [2-5].

DNA damage caused by the interaction of the charged alpha particles from the inhalation of radon with lung tissue can increase the risk of lung cancer, depending on the radon concentration and exposure time

Corresponding author : Hasan Rahimi, h.rahimi@iamr.ir, IAMR Co., Ltd., Iran
[6,7]; however, in accordance to the United States Environmental Protection Agency (EPA) report, radon is the second leading cause of lung cancer, after smoking [8]. ${ }^{226} \mathrm{Ra}$ is one of the commonly naturally occurring radioactive materials in the Earth's crust (rocks, stones, soils, etc.) [9]. Soil and stone, as feedstock in the building materials, contain amounts of ${ }^{226} \mathrm{Ra}$, which is what generates radon gas. The generated radon mainly migrates and enters dwellings through cracks in walls, basements, and foundations; however, the ground is the main source of radon. Tap water used in the kitchen or shower can be another source of radon in homes [10].

Exposure to a low level of outdoors radon concentration, due to its naturally occurring property, is likely impossible to avoid, while most exposure to radon originates from being within dwellings [9]. Several studies show that cigarette smoke and radon exposure can sep- 
arately increase the risk of lung cancer; however, exposure to both greatly enhances the risk of lung cancer [8].

There is no evidence to show that exposure to inhaled radon may have other side effects, such as other forms of cancer, respiratory diseases, or general physical symptoms (e.g., coughing or headaches) [11].

Depending on national and international recommendation and regulations, a range of 100 to 400 $\mathrm{Bq} / \mathrm{m}^{3}$ has been set as an indoor radon concentration reference level. International Commission on Radiological Protection (ICRP), World Health Organization (WHO), the European Union and United States Environmental Protection Agency (EPA) are the most popular indexes in the world whom provide recommendations and regulations for concentrations of radon in workplace and public $[8,11,12]$.

This paper presents the correlation between indoor radon concentration and the age of the building for the 30 representative houses in Mahallat city, Iran. Taking into consideration the radon concentration and the individual status of the household, the health risk of exposure to radon was determined to estimate the lung cancer risk associated with residential radon exposure for different categories of population: the general population; current smokers; those who have ever smoked; and never smokers. The annual effective dose received by residents was calculated to assess the potential of long-term effects.

\section{Study AREA}

Mahallat, with a population of approximately 53 thousand and $37 \mathrm{~km}^{2}$ areas, is one of the oldest cities in Iran. It is located in the Markazi state in the north-west of Iran (N $32^{\circ} 54^{\prime}$, E $\left.50^{\circ} 27^{\prime}\right)$ and is surrounded by mountains. About 30 representative houses, in the age range of 3 to 30 years after construction and from different locations of the city, were selected to measure indoor radon concentration. The representative houses were collected from a randomized sample of homes and were based on: the distribution of the population, used building materials, geological structure, ventilator system and the age of constructions to cover sampling from all different parts of the city; during sampling, the applicants were requested to fill out an introduction form, which included questions about the building, households habitats, the ventilation system and so on.

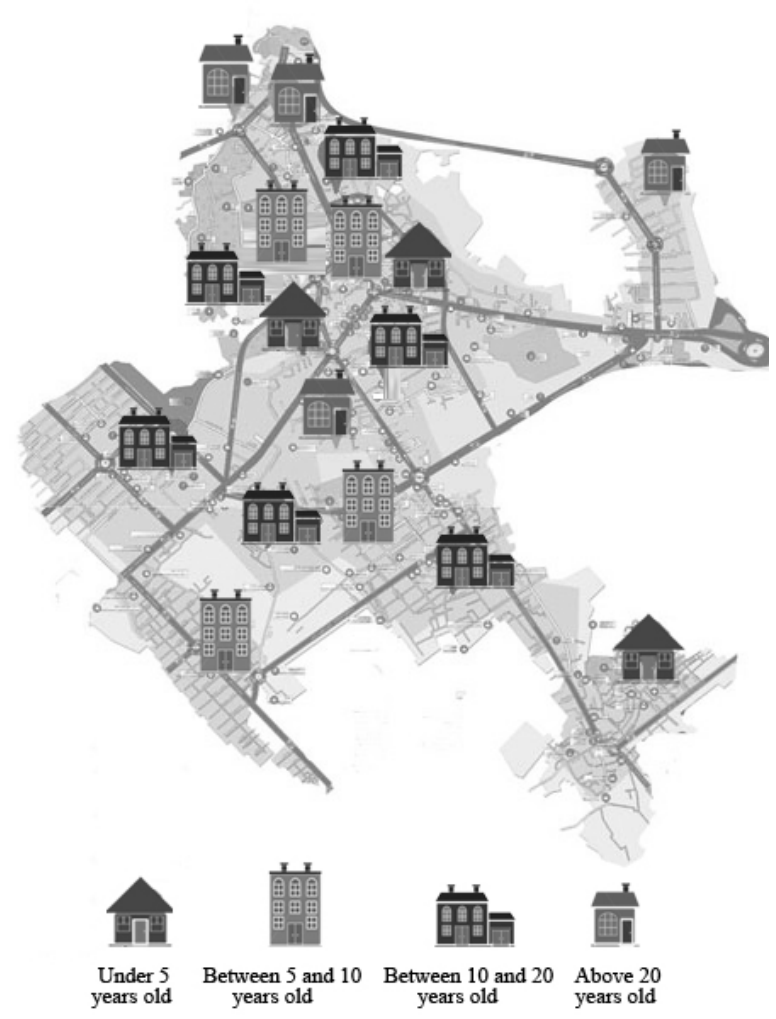

Fig. 1. The location of representative dwellings in terms of age.

Fig. 1 presents the distribution of the selected dwellings in terms of their age.

From each house, two places were selected to evaluate the radon activity concentration. These were the living room and bedroom, due to residents mostly spending their time in these rooms.

\section{MEASUREMENTS AND METHODS}

A time-integrated passive method was used to detect radon concentrations inside the houses. The CR-39 type detectors (SSNTD, Solid State Nuclear Track Detector, $10 \times 10 \mathrm{~mm}$ ) covering by radon selective diffusion containers $(35 \times 30 \times 10 \mathrm{~mm})$ were exposed to indoor radon of representative houses for 6 months. The charged alpha particles from radon decay collide with the surface of CR-39 and break the chemical bonds of the polymer structure what are called tracks [13]. The tracks were made visible by the chemical etching and then counted using optical transmission microscope and image analyzer software.

Two detectors - one in the living room and one in 
the bedroom - were placed in each house for 180 days (January to June) in order to show precise results of indoor radon concentrations in cold and warm seasons. The detectors were placed at the horizontal distance of $120-160 \mathrm{~cm}$ above the floor, $50 \mathrm{~cm}$ far from the doors and windows and $20 \mathrm{~cm}$ away from any other objects on the wall.

Etching solution was prepared as a $25 \% \mathrm{NaOH}$ solution on a hot plate. Detectors were floated in the etching solution at $90{ }^{\circ} \mathrm{C}$ for four hours [14]. The average radon concentration was then calculated by counting the tracks and Eq.1 [4,14]:

$$
\mathrm{C}_{R n}=\left(\mathrm{N}_{T}-\mathrm{N}_{B}\right) \mathrm{E} / \mathrm{TA}
$$

where $\mathrm{C}_{R n}$ is the average indoor radon concentration $\left(\mathrm{Bq} \cdot \mathrm{m}^{-3}\right), \mathrm{N}_{T}$ is tracks number, $\mathrm{N}_{B}$ is the background tracks, $\mathrm{E}$ is the calibration factor $\left(\mathrm{Bq} \cdot \mathrm{h} \cdot \mathrm{mm}^{2} \cdot \mathrm{m}^{-3}\right), \mathrm{T}$ is the exposed time (hours), and $\mathrm{A}$ is reading area of the detector $\left(\mathrm{mm}^{2}\right)$. The calibration factor $(\mathrm{E})$ is calculated from Equations (2) :

$$
\mathrm{E}=\mathrm{C}_{R n} \mathrm{TA} / \mathrm{N}
$$

where the $\mathrm{N}$ is the net tracks.

Radon decay product exposure rate is expressed as any combination of short-lived radon decay products in 1 cubic meter of air with the potential of emitting 20.8 $\mu \mathrm{J}$ of alpha particle energy and shows by WL unit [16]. Working Level Months is a unit of exposure to $1 \mathrm{WL}$ for 170 hours [8]. Annual radon progeny exposure is calculated with Equation (3) [8]. In the absence of experimental data on equilibrium factor between radon and its progeny in the representative houses, the EPA recommended value was used to estimate annual human exposure rate.

$$
\mathrm{WLM}_{(Y)}=\mathrm{C}_{R n} \mathrm{~F}\left(2.7 \times 10^{-4}\right) \mathrm{S}\left(\mathrm{H}_{\text {Year }} / 170\right)
$$

Where $\mathrm{WLM}_{(Y)}$ is the annual human exposure rate to radon decay products, $\mathrm{C}_{R n}$ is the average of radon concentration $\left(\mathrm{Bq} \cdot \mathrm{m}^{-3}\right), \mathrm{F}$ is the equilibrium factor as 0.4 for indoor and 0.6 for outdoor, $2.7 \times 10^{-4}$ is the radon progeny concentration in equilibrium $\left(\mathrm{WL} \cdot \mathrm{Bq} \cdot \mathrm{m}^{-3}\right), \mathrm{S}$ as 0.7 is the fraction of spending time indoors, and $\mathrm{H}_{\text {Year }}$ is annual hours.

The annual effective dose from inhaled radon is calculated with Equation (4) [5,17]:
Table 1. The Lung Cancer Risk Factors by Individual Status.

\begin{tabular}{ccc}
\hline Organization & Status & Risk Factor \\
\hline ICRP & General Population & $5 \times 10^{-4}$ \\
& Current Smoker & $1.5 \times 10^{-3}$ \\
\multirow{2}{*}{ EPA } & Ever Smoker & $9.68 \times 10^{-4}$ \\
& Never Smoker & $1.67 \times 10^{-4}$ \\
\hline
\end{tabular}

$$
\mathrm{H}_{A}=\mathrm{WLM}_{(Y)} \cdot \mathrm{I}
$$

Where $\mathrm{H}_{A}$ is annual effective dose $\left(\mathrm{mSv} \cdot \mathrm{y}^{-1}\right)$ and $\mathrm{I}$ is the conversion factor of 9 ( $\mathrm{mSv}$ per WLM).

The risk factors provided by ICRP and EPA were used to estimate the risk of lung cancer from radon inhalation for: the general population, current smokers, ever smokers, and never smokers. Table 1 presents the risk factors in terms of organisations and individual status.

The annual risk of lung cancer from inhaled radon and its progeny is calculated by equation number 5 [8]:

$$
\mathrm{R}=\mathrm{WLM}_{(Y)} \mathrm{DK}
$$

where $\mathrm{R}$ is the risk of lung cancer per year, $\mathrm{WLM}_{(Y)}$ is the annual cumulative radon and its progeny exposure rate, $\mathrm{D}$ is the exposure time (Year) and $\mathrm{K}$ is the risk factor.

\section{System calibration and characterization}

The detectors were calibrated using a lake-proof radon chamber and a passive radon source to supply a known concentration of radon inside the chamber [15]. Radon concentration inside the chamber was monitored

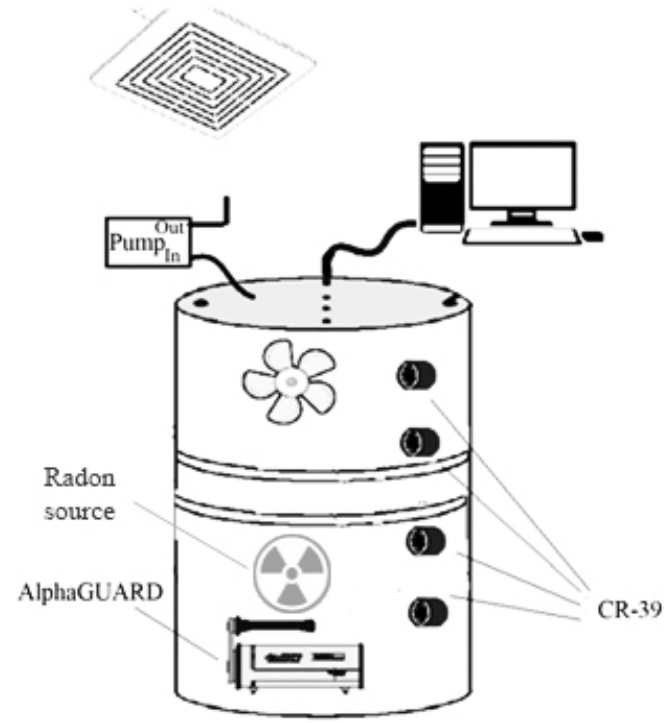

Fig. 2. The perspective of CR-39 calibration system. 
Table 2. The ${ }^{222} \mathrm{Rn}$ Concentration, Effective Dose and Lung Cancer Risk for Representative Houses.

\begin{tabular}{|c|c|c|c|c|}
\hline Type & Location & ${ }^{*} \mathrm{C}_{\mathrm{Rn}}$ & Annual dose & "Ge risk \\
\hline \multirow{10}{*}{$\begin{array}{c}\text { Ground } \\
\text { Level }\end{array}$} & S-01 & $177 \pm 13$ & $6 \pm 0.4$ & 0.03 \\
\hline & S-02 & $248 \pm 18$ & $9 \pm 0.7$ & 0.05 \\
\hline & S-03 & $202 \pm 15$ & $7 \pm 0.5$ & 0.04 \\
\hline & S-04 & $157 \pm 12$ & $5 \pm 0.4$ & 0.03 \\
\hline & S-06 & $103 \pm 8$ & $4 \pm 0.3$ & 0.02 \\
\hline & S-07 & $168 \pm 12$ & $6 \pm 0.4$ & 0.03 \\
\hline & S-08 & $281 \pm 21$ & $10 \pm 0.8$ & 0.05 \\
\hline & S-09 & $145 \pm 11$ & $5 \pm 0.4$ & 0.03 \\
\hline & S-10 & $198 \pm 15$ & $7 \pm 0.5$ & 0.04 \\
\hline & S-11 & $179 \pm 13$ & $6 \pm 0.5$ & 0.03 \\
\hline \multirow{7}{*}{$\begin{array}{l}\text { Walk-up } \\
\text { Basement }\end{array}$} & $1-\mathrm{S} 02$ & $286 \pm 21$ & $10 \pm 1$ & 0.06 \\
\hline & 2-S03 & $304 \pm 23$ & $11 \pm 1$ & 0.06 \\
\hline & 3-S06 & $271 \pm 20$ & $9 \pm 0.7$ & 0.05 \\
\hline & 4-S07 & $238 \pm 17$ & $8 \pm 0.6$ & 0.05 \\
\hline & 5-S08 & $350 \pm 26$ & $12 \pm 0.9$ & 0.07 \\
\hline & $6-\mathrm{S} 10$ & $233 \pm 17$ & $8 \pm 0.6$ & 0.05 \\
\hline & 7-S04 & $268 \pm 19$ & $9 \pm 0.7$ & 0.05 \\
\hline \multirow{4}{*}{$\begin{array}{l}2^{\text {nd }} \text { Floor } \\
\text { Apartment }\end{array}$} & A01-2 & $30 \pm 2$ & $1 \pm 0.2$ & 0.01 \\
\hline & A02-2 & $27 \pm 3$ & $1 \pm 0.1$ & 0.01 \\
\hline & A03-2 & $28 \pm 2$ & $1 \pm 0.1$ & 0.01 \\
\hline & A04-2 & $23 \pm 2$ & $1 \pm 0.1$ & 0.01 \\
\hline \multirow{5}{*}{$\begin{array}{c}1^{\text {st }} \text { Floor } \\
\text { Apartment }\end{array}$} & A01-1 & $40 \pm 3$ & $1 \pm 0.1$ & 0.01 \\
\hline & A02-1 & $41 \pm 3$ & $1 \pm 0.1$ & 0.01 \\
\hline & A03-1 & $45 \pm 4$ & $2 \pm 0.1$ & 0.01 \\
\hline & A04-1 & $30 \pm 3$ & $1 \pm 0.1$ & 0.01 \\
\hline & A05-1 & $52 \pm 5$ & $2 \pm 0.1$ & 0.01 \\
\hline
\end{tabular}

${ }^{*} \mathrm{Rn}$ is indoor radon concentration $\left(\mathrm{Bq} \cdot \mathrm{m}^{-3}\right)$, Annual dose is annual effective dose from inhaled radon $\left(\mathrm{mSv} \cdot \mathrm{y}^{-1}\right)$ and Ge risk is annual lung cancer risk to the general population $(\%)$. during calibration using AlphaGUARD. The radon concentration inside the chamber was kept constant during the whole experiment by adjusting the flow rate of the pump. Detectors were exposed at $2000 \mathrm{~Bq} \cdot \mathrm{m}^{-3}$ radon concentration for seven days. Fig. 2 shows a schematic diagram of the calibration system.

\section{RESULTS AND DISCUSSIONS}

Table 2 shows the indoor radon concentration in representative houses. The radon concentrations were measured between $23 \pm 2$ and $350 \pm 6 \mathrm{~Bq} \cdot \mathrm{m}^{-3}$ with an average of $158 \mathrm{~Bq} \cdot \mathrm{m}^{-3}$; however, the average of measured radon concentration is higher than the worldwide average value at $39 \mathrm{~Bq} \cdot \mathrm{m}^{-3}$ (UNSCEAR, Effects of Atomic Radiation), and EPA recommend levels at 100 $\mathrm{Bq} \cdot \mathrm{m}^{-3}$, however this is below the WHO, EU BSS (European Basic Safty Standard), and ICRP recommended reference level $\left(300 \mathrm{~Bq} \cdot \mathrm{m}^{-3}\right)[1,8,12]$.

The average of indoor radon concentration in walkup basement houses, ground level houses, basement apartments, and $1^{\text {st }}$ and $2^{\text {nd }}$ floor apartments, were calculated as $292,186,132,41$, and $27 \mathrm{~Bq} \cdot \mathrm{m}^{-3}$, respectively.

An association between the age of the dwellings and the concentration of radon was found, in that the radon concentration tends increase as the age of the dwelling also increases. Fig. 3 shows the relation between the radon concentration and the age of the houses - walk-up basement, ground level and basement apartments - that were similar in geology and climate.

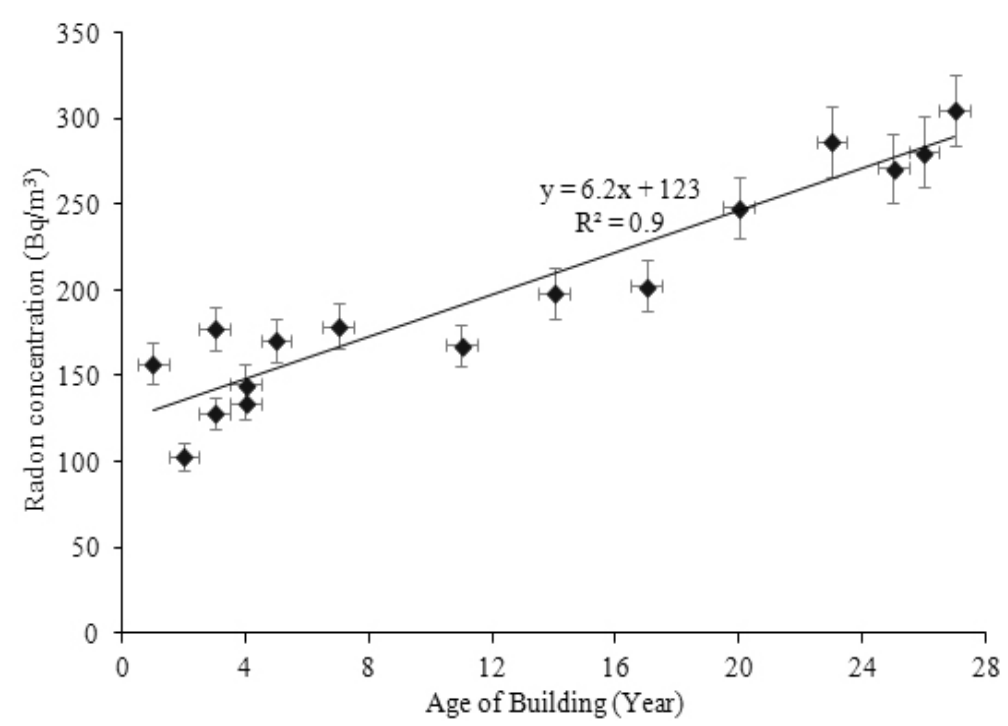

Fig. 3. The correlation between indoor radon concentration and the age of the house. 


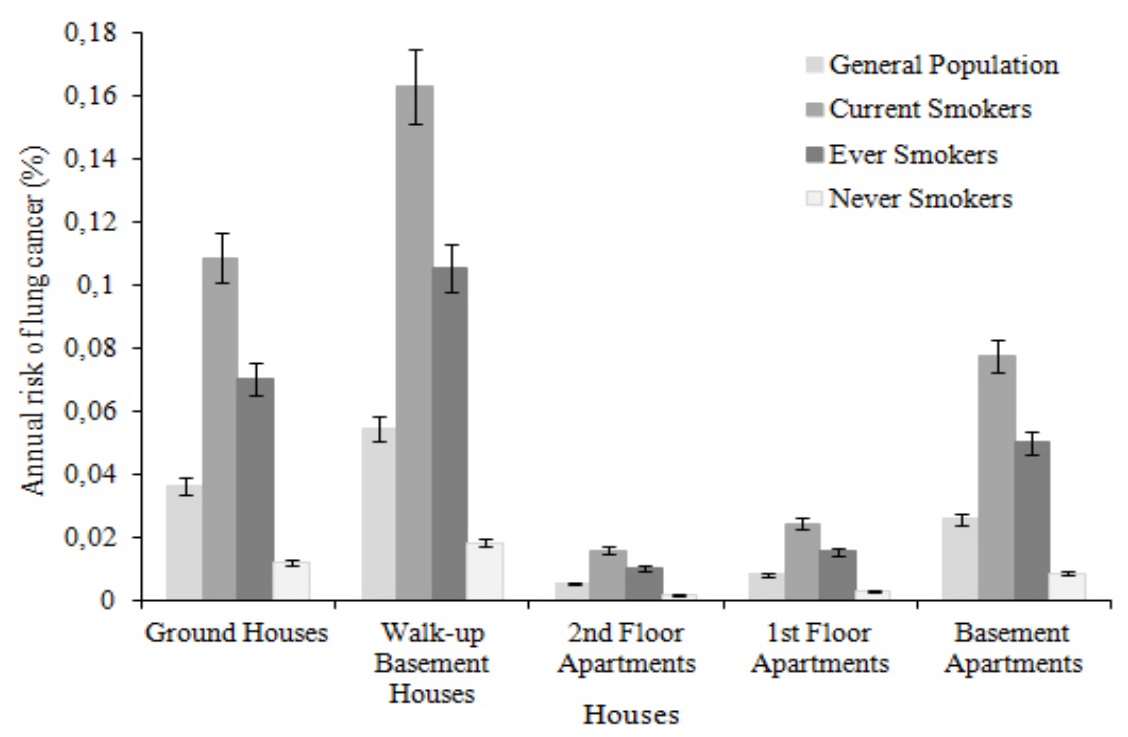

Fig. 4. The annual risk of lung cancer in terms of building style.

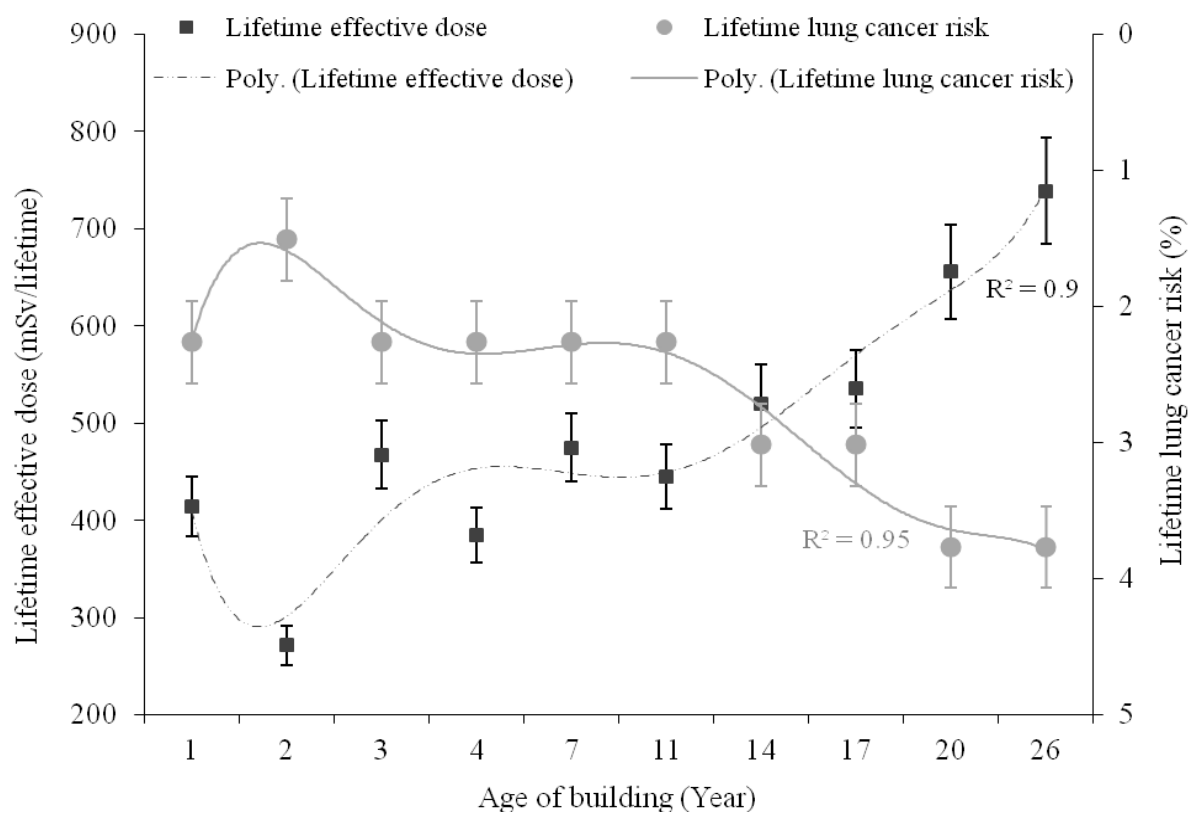

Fig. 5. Lung cancer risk and effective dose in terms of building age.

Yearly exposure rates to radon and its progeny were measured from 0.09 to $1.36 \mathrm{WLM}_{(Y)}$ with an average of $0.62 \mathrm{WLM}_{(Y)}$. Table 2 presents the annual effective dose from inhaled radon for each house.

The annual effective dose rates were calculated between 0.8 and $12 \mathrm{mSv}^{-1} \mathrm{y}^{-1}$ with an average of $5.5 \mathrm{mSv}$. $\mathrm{y}^{-1}$; mainly, the measured annual effective dose rates were within the recommended reference level at 3 to 10 $\mathrm{mSv} \cdot \mathrm{y}^{-1}$ of the international organisations [18].

In addition, the yearly risk of lung cancer was estimated for four different categories of smokers, ever smokers, never smokers and the general population. The annual risk of lung cancer for each category in terms of house type is shown in Fig. 4.

Lifetime lung cancer risk was calculated by multiplying the annual lung cancer risk of each category with the lifespan of the categories set for different smokers. In accordance with the EPA statement, the lifespan for never smokers, ever smokers, and the general population are about $76.4,74.2$, and 75.4 years, respectively [8]. Fig. 5 shows the lifetime lung cancer risk and the lifetime effective dose in terms of ground house age.

According to the results of the study, a possible effect of house age on indoor radon concentration was observed, however it cannot be approved due to vary- 
ing reasons, for example, the air tightness of earthneighbouring building elements, induced radon concentration, and the amount of used building material. According to $\mathrm{Yu}$ KN's study, (The variation of radon exhalation rates from building surfaces of different ages, 1995), the radon exhalation rate from the building's surface decreases as the building age increasing [19]. However, Cohen BL (1986) observed that there is a positive correlation between indoor radon concentrations and age of houses [20].

It is clear that approximately all selected houses including old, recently built, and new - do not have radon concentrations that exceed the recommended levels.

\section{CONCLUSIONS}

In conclusion, the results show that the average of indoor radon concentrations of dwellings in Mahallat city are below the European and ICRP recommendation levels, in exception of dwelling numbers 2-S03 and 5-S08 as 305 and $350 \mathrm{~Bq} \cdot \mathrm{m}^{-3}$, respectively. The annual effective doses are mainly below the recommendation level, with an average of $5.5 \mathrm{mSv} \cdot \mathrm{y}^{-1}$; however, the annual risks of lung cancer were estimated at $0.2 \%$ in all population categories. The observed results of this study are consistent with a previous study by Cohen BL ("A national survey of ${ }^{222} \mathrm{Rn}$ in U.S. homes and correlating factors", 1991), in that the radon concentration in houses with an average age of less than 20 years old was measured around 33\% higher than houses with an average age of more than 10 years. In regards to the risk of lung cancer, a mitigation act is recommended for all dwellings with a radon concentration higher than $200 \mathrm{~Bq} \cdot \mathrm{m}^{-3}$; however, huge amounts of radon enters the home from the ground, therefore ground isolation for old houses are recommended.

\section{REFERENCES}

1. Duggal V, Rani A, Mehra R. Measurement of indoor radon concentration and assessment of doses in different districts of Northern Rajasthan, India. Indoor Built Environ. 2014;23:1142-1150.

2. Lecomte JF, Solomon S, Takala J, Jung T, Strand P, Murith C, Kiselev S, Zhuo W, Shannoun F, Janssens A. Radiological protection against radon exposure. Ann ICRP. 2014; 43(3):5-73.

3. United Nations Scientific Committee on the Effects of Atomic Radiation. Sources and effects of ionizing radiation. Vol 1. United Nations. 2000.

4. Saada AF, Al-Awamia HH, Husseina NA. Radon exhalation from building materials used in Libya. Radiat Phys Chem. 2014;101:15-19.

5. Kapdana E, Altinsoy N. A comparative study of indoor radon concentrations between dwellings and schools. Radiat Phys Chem. 2012;81(4):383-386.

6. Wichmann HE, Rosario AS, Heid IM, Kreuzer M, Heinrich J, Kreienbrock L. Increased lung cancer risk due to residential radon in a pooled and extended analysis of studies in Germany. Health Phys. 2005;88:71-75.

7. Tarsheen KS, Moataz N E, Goetz H, Kloecker H K.. Radon and Lung Cancer. Clin Adv Hematol Oncol. 2012;10(3):157-164.

8. Environmental Protection Agency (EPA) . EPA assessment of risks from radon in homes. U.S. Environmental Protection Agency; 2003.

9. Shahrokhi A, Szeiler G, Rahimi H, Kovács T. Investigation of natural and anthropogenic radionuclides distribution in arable land soil of south eastern European countries. IJSER Research. 2014; 5(11):445-449.

10. The World Health Organization. WHO handbook on indoor radon: a public health perspective. In Hajo Z, Ferid S (eds). Geneva; WHO Press. 2009.

11. The World Health Organization. Air quality guidelines for Europe. 2nd ed. Europe; WHO Regional Publications, 2000

12. The council of the European Union. DIRECTIVE 2013/59/EURATOM. OJEU. 2014; L13(57):1-73.

13. Daraktchieva Z, Howarth CB, Algar R. Results of the 2012 HPA intercomparison of passive radon detectors. Chilton; Public Health England, 2013.

14. Lamonaca F, Nastro V, Nastro F, Vasile M, Nastro2 A. Evaluation of the relation between building materials and indoor radon pollution. Proceedings 4th Imeko TC19 Symposium on Environmental Instrumentation and Measurements. 2013 June.

15. Mamont-Cieśla K, Stawarz O, Karpińska M, Kapała J, Kozak K, Grządziel D, Chałupnik S, Chmielewska I, Olszewski J, Przylibski TA, Żebrowski A. Intercomparison of radon CR-39 detector systems conducted in CLOR's calibration chamber. Nukleonika. 2010; 55(4):589-593.

16. U.S. Environmental Protection Agency. Protocols 
for radon and radon decay produc measurements in homes. EPA 402-R-92.003. 1993.

17. Marsh JW, Harrison JD, Laurier D, Blanchardon E, Paguet F, Tirmarche M. Dose conversion factors for radon: recent developments. Health Phys. 2010; 99(4):511-516.

18. Rohit M, Pankaj B. Estimation of annual effective dose due to radon level in indoor air and soil gas in Hamirpur district of Himachal Pradesh. J Geochem Explor. 2014; 142:16-20.
19. Yu KN, Chan TF, Young EC. The variation of radon exhalation rates from building surfaces of different ages. Health Phys. 1995; 68(5):716-718.

20. Cohen BL. A national survey of ${ }^{222} \mathrm{Rn}$ in U.S. homes and correlating factors. Health Phys. 1986; 5(1):175-183. 